\title{
The Different Impact of Top Executives' Turnover on Healthy and Restructured Companies
}

\author{
Carla Morrone ${ }^{1}$, Alberto Tron ${ }^{2}$, Federico Colantoni ${ }^{2} \&$ Salvatore Ferri $^{1}$ \\ ${ }^{1}$ Department of Business and Economics, University of Naples Parthenope, Naples, Italy \\ ${ }^{2}$ Department of Finance, University of Milan Bocconi, Milan, Italy \\ Correspondence: Carla Morrone, Department of Business and Economics, University of Naples Parthenope, \\ Naples, Italy, Via Generale Parisi, 13 - 80132 Naples (NA), Italy. E-mail: carlamorrone@hotmail.it
}

Received: October 1, 2021

doi:10.5539/ijbm.v17n1p17
Accepted: November 18, 2021

URL: https://doi.org/10.5539/ijbm.v17n1p17

\begin{abstract}
The aim of this paper is to investigate if top executives' turnover affects the performance of a company and if it differently impacts the performances of a healthy and a restructured company. In order to investigate the impact of the renewal of both members of the board of directors and CEO impacts on company profitability, we performed a quantitative analysis based on a sample of 144 Italian companies using a logit model. The findings show that management changes influence the performance of a company. However, the results show a different impact for healthy and restructured companies. The renewal of the board of directors negatively affects the performances of a healthy company while influences positively the probability of a future increase in performances for restructured companies, suggesting useful implications for scholars and practitioners. This analysis confirms that the renewal of top executives can affect the probability of an increase of company performances, especially for distressed firms, contributing to existing literature which is still limited and focused only on few countries.
\end{abstract}

Keywords: corporate governance, crisis, performances, restructuring, turnaround

\section{Introduction}

As highlighted by Ernst and Young (2010), more than $80 \%$ of managers think that innovation in management processes is a critical component for the growth of an organization. The Chief Executive Officer (CEO) of a company and its board of directors are the most powerful figures inside a company (Linck, Netter \& Yang, 2008). They have a critical role in guiding and determining the strategy of a company, and, thus, on its performances. In this context, we presume that top executives (CEO and directors) are a firm's key factor represented by professional background, entrepreneurship, skills, knowledge, and internal and external relationships (Mazzotta, 2018; Paoloni, Mattei, Dello Strologo \& Celli, 2020) and that introducing new human and relational capital (Chen, Liu, Chu, \& Hsiao, 2014; Berezinets, Garanina, \& Ilina, 2016; Agostini \& Nosella, 2017) can help to raise the competitiveness of a company. Therefore, it is not a surprise that the relationship between company performances and board of directors has been extensively researched over recent decades (e.g.: Ben Barka \& Legendre, 2016; Malik \& Makhdoom, 2016; Mishra \& Kapil, 2017; Scafarto, Ricci, Della Corte, \& De Luca, 2017). However, the results have been mixed and inconclusive (Scafarto et al., 2017) and focused mainly on geographical contexts like U.S., China and UK; indeed, the overall analysis of this issue for other countries is still lacking (Manzaneque, Priego, \& Merino, 2016). Moreover, despite the increasing interest, due to the relevance assumed by corporate crisis in the current and past socio-economic contexts, the relationship between the role of top executives turnover and the turnaround in prior empirical research has been not yet analysed in-depth (Miglani, Ahmed, \& Henry, 2020)

Thus, the aim of this paper is to investigate, through an empirical analysis based on a sample of 144 Italian companies, if management changes (CEO and board members) affect firm performances. More particularly, this paper contributes to the existing literature by comparing, using an interaction factor, how the turnover of the board of directors and of the CEO differently influence firm performances of healthy and restructured companies. Italy is a good sample to show the importance of how directors could improve or solve some issues that could affect distressed companies. In particular, Italy is the third Country for GDP in Europe and ninth in the world and, it is typically characterized by non-listed family firms, which tend to take higher levels of risk than non-family 
firms (Contreras, Arias, \& Maquieira., 2021) and are normally not able to renew the management (or the original entrepreneur).

Final results show that the renewal of the board of directors negatively impacts the probability of an increase in the performance of a healthy company. On the contrary, the turnover of the board of directors positively affects the performances of a restructured company, corroborating the necessity of the renewal of the management during a turnaround.

\section{Literature Review}

The turnover of top executives has attracted significant attention in the existing literature. The power to change the CEO rests with the board of directors of a firm. However, the board of directors, especially in Italy, can face delicate situations due to a lack of independence or unclear performance evaluation standards (Hilger, Mankel, \& Richter, 2013).

Top executive turnover may occur for several reasons: i) normal routine changes (e.g., retirements, career or family reasons), ii) forced departure (Hilger et al., 2013). The first studies on the reason for CEO turnover and firm performance were conducted in the 1980s (Coughlan \& Schmidt, 1985) and they showed that firms with poor performance tend to change more frequently the CEO or the board of directors (Pukthuanthong, Ullah, Walker, \& Zhang, 2018).

Subsequently, scholars have extensively analyzed the impact of CEO/board of directors' characteristics on firm performance. Various papers tried to study different elements, such as demographic background (Lohrke, Bedeian \& Palmer, 2004), top management team replacement (Sudarsanam \& Lai, 2001; Aghamolla \& Hashimoto, 2021), CEO characteristics (Abebe \& Tangpong, 2009; Miglani, 2014; Susi \& Lukason, 2017) and insider representation on board (Judge \& Zeithmal, 1992). However, existing empirical evidence is generally ambiguous and mixed (Scafarto et al., 2017; Minichilli, Zattoni, \& Zona, 2009). Indeed, researchers have found both a positive linkage (e.g. Kowalewski, Stetsvuk, \& Talavera, 2010; San Martin-Reyna \& Duran-Encalada, 2012) and a negative relationship (e.g. Guest 2009; Jackling \& Johl, 2009; Adams \& Ferreira, 2009) between board characteristics and firm value.

More interesting for our aim is the research focused on composition changes of CEO and board of directors (Gilson, 1990; Denis \& Denis, 1995; Elloumi \& Gueyié, 2001, Lambertides, 2009; O’Kane \& Cunningham, 2012; Deng, Intintoli, \& Zhang, 2019; Bennedsen, Pérez-González, \& Wolfenzon, 2020). However, results are still contradictory, highlighting both positive (Lambertides, 2009; Bennedsen et al., 2020) and negative impact (Hilger et al., 2013) of top executives' turnover on company performances. According to the existing literature, if the management team affects the firm performance (Barrick, Day, Lord, \& Alexander, 1991; Yukl, 2008), its replacement should impact future profitability. New executives can use the momentum following the dismissal for proposing radical changes in the company facilitating the introduction of innovative processes/products and, thus, sustaining the future development of the company (Hilger et al., 2013). Therefore, an improvement in the company profitability can be considered as a signal of the positive effects of top executives' turnover (Denis \& Denis, 1995). However, top executives' turnover can be disruptive, and, therefore detrimental to firm performance in the short-run or even in the long run. Moreover, as suggested by Brown (1982), the dismissals of the old management team could be just partial and illusory, without long-term effects on company profitability, except a possible positive impact in the short run. Therefore, the effects on the company performance of the managers depend largely on the selection process, on the choices of successors and on the integration of the new manager into the organization and its decision-making structure (Finkelstein, Hambrick, \& Cannella Jr., 2009).

Similarly, several studies pointed out as strategic changes are essential to survive in tempestuous environments (Dunphy \& Stace, 1988; Kanter, Stein, \& Jick, 1992; Garzella 2005; Dallocchio, Ferri, Tron, \& Vizzaccaro, 2020) like a turnaround process. As shown by various authors (Lohrke, Bedeian, \& Palmer, 2004; Lappalainen \& Niskanen, 2012; Alipour, 2013; Pham \& Nguyen, 2020), top executives are essential figures to promote a new organizational structure with a significant impact on corporate performance and hence, we think, their renewal is a strategic change, necessary in a turnaround (Pressman, 2007). Indeed, various analyses focus on the impact of leadership changes in reverting a corporate crisis, highlighting that the C-level managers changing in declining firms is positively related to effective turnarounds (Mueller \& Barker III 2002). However, other scholars believe that this relation does not exist (Sudarsanam \& Lai 2001) or, anyway, is not properly demonstrated (Pitcher, Chreim, \& Kisfalvi, 2000; Daily \& Dalton 1994). For example, Mueller and Barker III (2002) observe that, despite the relevance of strategic leadership, a top management team change was not a strong predictor of crisis passing.

Hence, our research aims to empirical proof if the turnover of the board of directors can impact the performance 
of companies, especially for distressed firms. From the review of prior research, it is clear that the topic is far from a new issue, however, previous results are still mixed. Furthermore, the special characteristics of corporate governance in Italy (high ownership concentration, governance practices) can create serious agency conflicts, especially after the Covid-19 as suggested by Zattoni and Pugliese (2020). Therefore, the analysis of the relationship between the replacement of CEO and board of directors' and companies' performance for Italy provides evidence for this type of context, where overall analysis of this issue is still lacking (Manzaneque et al., 2016).

\subsection{Hypotheses Development}

Assuming the importance of both board of directors (BoD) members and the CEO on company profitability, especially during a corporate turnaround, we want to investigate the following hypotheses:

HP 1. the renewal of BoD members influences the performance of a company, especially during a turnaround.

HP 2. the replacement of CEO influences the performance of a company, especially during a turnaround.

We test these two hypotheses based on a logit model.

\section{Materials and Methods}

\subsection{Methodological Approach}

As for the methodology, a binary logistic regression (BLR) model is carried out using Stata (Note 1). The logit model allows us to predict the log odds of outcomes of a categorical dependent variable from the set of independent variables that may be continuous, discrete, and/or categorical (Hilbe, 2009; King, 2008).

In this paper, binary logistic regression is used to predict the impact on company performances following the renewal of both BoD members and CEO.

The BLR fits the data of this study because independent variables do not must be normally distributed or have equal variance in each group and they do not need to be linearly related with the dependent one and the assumption of being homoscedastic (Hilbe, 2015). Furthermore, a binary logistic regression is suitable for developing predictive models for financial performance with binary events, such as win/loss and fail/pass (Omondi-Ochieng, 2020).

\subsection{Sample}

Thanks to the support of an Italian leading bank, we access to the 2014 database of socalled "unlikely to pay" (UTP) positions, listing distressed companies from a bank's perspective, even though they are not involved in a legal state of crisis (e.g., bankruptcy and debt restructuring agreements). This special database details companies that show problems in meeting financial obligations contracted with the bank. Therefore, the concept of crisis adopted in this paper arises from an unusual approach; the most common definition of corporate crisis implemented in literature for empirical studies refers to the state of crisis only from a legal point of view, considering when companies access to a "formal procedure" stated by bankruptcy law. Our interpretation, instead, is broader and independent from the access to one of the procedures governed by the law.

Using bank's information system, from the UTP list of 10,143 entities, related to 2,294 corporate groups, we considered only those that concluded a turnaround process, identifying 232 business cases, of which 12 refer to foreign companies excluded from our sample. About the remaining 220 Italian corporations, we could distinguish two possible outcomes of the financial restructuring process: (i) complete the rehabilitation of a company in its capacity to repay debts ("in bonis" status) and (ii) confirm the inability to repay financial obligations due to the deep state of crisis ("workout" status).

The extraction from bank's information system identified 72 companies (without including the listed ones) with "in bonis" status.

For each of these 72 companies ("restructured companies"), we firstly extracted from the bank's information system both governance and economic-financial data and then integrated the database with data from CERVED (for governance data) and from Bureau van Dijk's AIDA and Amadeus (for economic-financial data).

Data extraction refers to a ten-year period in which the firm had a "crisis moment" (i.e., the date of recording in the Register of UTP).

After having identified the sample of 72 companies, another sample, through the following process, was considered to reach the target of this study:

1) Starting from the economic-financial data of each entity in our sample, the maximum, minimum, and mean 
values of the turnover have been considered as an approximation of the company size.

2) For each company in the sample, the sector of business was identified.

3) Given the entire population of Italian companies included in the dimensional limits of our sample, only companies with the same 2007 ATECO (Note 2) were considered.

4) Referring to the latter population, using a process of pairwise sampling companies, 72 "healthy" were selected.

Hence, the final sample that allows us to achieve statistically robust results - including the two subsamples - is composed of the following 144 companies:

- 72 companies (called "restructured companies") that in the period exanimated were able to repay their obligations to the bank.

- 72 companies (called "healthy companies") that did not be distressed during the period 2007-2016.

\subsection{Model}

We set up a model including both healthy and successfully restructured companies to investigate the impact of the renewal of the CEO and board of directors on company performances.

As an indicator of the firm performance, we use the ROA, which has been used extensively in past corporate governance and management research (e.g Terjesen, Couto, \& Francisco, 2016; Pèrez-Calero, del Mar Villegas \& Barroso, 2016; Ben Barka \& Legendre, 2016; Scafarto et al., 2017). ROA is calculated as the ratio of net income to total assets. According to the research design above, we created a dummy dependent variable: companies with an increase in the average ROA from the period 2012-2014 to the period 2014-2016 are coded 1, while the remaining ones are coded 0 .

Independent variables are:

- "Dummy BoD changes" that is a dummy variable coded to 1 if there were changes in the members of the BoD during the period 2012-2014;

- "Interaction Factor Status - BoD changes" that is an interaction factor between the variable Dummy $\mathrm{BoD}$ changes and the variable Status;

- "Dummy CEO changes" that is a dummy variable coded to 1 if there was a turnover of the CEO during the period 2012-2014;

- "Interaction Factor Status - CEO changes" that is an interaction factor between the variable Dummy CEO changes and the variable Status.

As a control variable, firm size and leverage, which have been shown to affect the management-performance relationship (Dalton, Daily, Ellstrand, \& Johnson, 1998), are used:

- "Dummy Size" measured as the total assets. This is a dummy variable coded to 1 if there was an increase in the total assets of the company from the period 2012-2014 to the period 2014-2016;

- "Dummy Leverage" measured by the ratio of total debt to total assets. This is a dummy variable coded to 1 if there was an increase in the leverage of the company from the period 2012-2014 to the period 2014-2016.

- "Status" that is a dummy variable coded to 0 for healthy companies and 1 for restructured companies.

The model used to estimate the binary logistic regression is Logit

$(P i / 1-P i)=\beta 0+\beta 1$ Dummy BoD changes $+\beta 2$ Interaction Factor BoD changes $+\beta 3$ Dummy CEO changes + $\beta 4$ Interaction Factor CEO changes $+\beta 5$ Dummy Size $+\beta 6$ Dummy Leverage $+\beta 7$ Status

where $\beta 0$ is the intercept, $\beta 1, \beta 2, \beta 3, \beta 4, \beta 5, \beta 6$ and $\beta 7$ are the regression coefficients of $x 1, x 2, x 3, x 4, x 5, x 6$ and $\mathrm{x} 7$, respectively, and Logit $(\mathrm{Pi} / 1-\mathrm{Pi})$ is the logarithm of the ratio between the odd that companies successfully overcome a crisis and the odd of not overcoming a crisis. 


\section{Results}

In Table 1 the descriptive statistics is reported.

Table 1. Descriptive statistics

\begin{tabular}{lllllll}
\hline & $\mathrm{N}$ & $\mathrm{P} 1$ & Mean & P50 & P99 & St. Dev. \\
\hline LnROA & 144 & 0.00 & 0.67 & 1.00 & 1.00 & 0.47 \\
Status & 144 & 0.00 & 0.50 & 0.50 & 1.00 & 0.50 \\
CEO changes & 144 & 0.00 & 0.35 & 0.00 & 3.00 & 0.76 \\
BoD changes & 144 & 0.00 & 1.38 & 0.00 & 13.00 & 2.69 \\
LnSize & 144 & -2.51 & -0.08 & 0.01 & 0.49 & 0.50 \\
Leverage & 144 & -4.09 & 3.62 & 0.11 & 4.97 & 3.23 \\
\hline
\end{tabular}

In Table 2 the correlation analysis is reported.

Table 2. Correlation analysis

\begin{tabular}{lllllll}
\hline & Dummy ROA & Status & $\begin{array}{c}\text { Dummy } \\
\text { changes }\end{array}$ & $\begin{array}{c}\text { CEO } \\
\text { Dummy } \\
\text { changes }\end{array}$ & BoD Dummy Size & $\begin{array}{l}\text { Dummy } \\
\text { Leverage }\end{array}$ \\
\hline Dummy ROA & 1.00 & & & & & \\
Status & $0.25^{* * *}$ & 1.00 & & & & \\
Dummy CEO changes & 0.07 & $0.16^{*}$ & 1.00 & & & \\
Dummy BoD changes & -0.05 & $0.25^{* * *}$ & $0.34^{* * *}$ & 1.00 & & 1.00 \\
Dummy Size & 0.04 & $-0.38^{* * *}$ & -0.07 & -0.05 & 0.07 & 1.00 \\
Dummy Leverage & $-0.25^{* * *}$ & $-0.25^{* * *}$ & -0.07 & $0.15^{*}$ & 0.07 & \\
\hline
\end{tabular}

Notes. $* * *, * *$, and $*$ indicates statistically significant levels of $1 \%, 5 \%$ and $10 \%$, respectively.

The correlation analysis shows a positive and significant relationship between the status of the company and the increase of the performance.

In order to test for multicollinearity, we also performed the VIF test. In any case, the variance inflation factor was not higher than two, therefore, we did not have any signs of serious multicollinearity requiring correction. Results are reported in Table 3.

Table 3. VIF test

\begin{tabular}{ll}
\hline & VIF Test \\
\hline Status & 1.36 \\
Dummy CEO changes & 1.16 \\
Dummy BoD changes & 1.27 \\
Dummy Size & 1.17 \\
Dummy Leverage & 1.14 \\
\hline
\end{tabular}

In Table 4 the results of the binary logistic regression are reported. 
Table 4. Logit results

\begin{tabular}{ll}
\hline Dependent variable & Dummy ROA \\
\hline Independent variables & \\
Status & 0.88 \\
& $(0.62)$ \\
Dummy CEO changes & 0.88 \\
& $(0.79)$ \\
Interaction Factor Status - CEO changes & -0.81 \\
& $(1.05)$ \\
Dummy BoD changes & $-1.28^{* *}$ \\
Interaction Factor Status - BoD changes & $(0.63)$ \\
& $1.53^{*}$ \\
Dummy Size & $(0.89)$ \\
& $0.81^{*}$ \\
Dummy Leverage & $(0.46)$ \\
& $-0.90^{* *}$ \\
Costant & $(0.41)$ \\
Observations & 0.29 \\
\hline
\end{tabular}

Notes. ${ }^{* *}, * *$, and $*$ indicates statistically significant levels of $1 \%, 5 \%$ and $10 \%$, respectively.

As expected, results show that the renewal of the board of directors' members is statistically significant at $5 \%$ and, therefore, affects the probability of an increase of the company profitability. However, the sign of the coefficient (-1.28) confirms a negative relationship between the turnover of the board of directors and the dummy dependent variable. Also, the interaction factor between the BoD and the status of the company is statically significant at $10 \%$ in the binary logistic regression with a (expected) positive coefficient $(+1.53)$. On the contrary, both the CEO turnover and the interaction factor between the CEO and the status of the company are not statistically significant. As displayed in Table 4 both control variables are significant.

Therefore, the results of the model confirm only our second hypothesis. Specifically, according to the logit model, the most impacting variable for affecting the company profitability is the renewal of the board of directors, however, the results are different for healthy and restructured companies. In particular, for healthy companies the $\mathrm{BoD}$ turnover has a negative effect on the increase of company profitability, while for restructured companies the impact is positive due to the effect of the interaction factor. The negative effects of BoD turnover on healthy companies could be explained by the peculiar corporate governance features of Italy. The Italian industrial system is characterized by a high percentage of family firms that tend to be more profitable than companies owned by diverse shareholders (Lee, 2006). Therefore, since the renewal of the board of directors in Italy is typically associated with a change of the ownership of the company (Dallocchio, Lucchin, \& Pirrone, 2021), this could cause, at least in the following three years, a decrease in the company profitability. On the contrary, restructured companies with a change in the composition of the $\mathrm{BoD}$ have more probability to increase their profitability and, thus, of exiting successfully from a turnaround. These results corroborate the thesis of existing literature (e.g. Fernando, Li, Hou, \& Yang, 2020). On the contrary, the renewal of the CEO is not statically significant. Also, in this case, this could be a direct consequence of the fact that Italy is characterized by family-owned firms. Therefore, the new CEO is still an expression of the same shareholder without the real possibility of introducing or applying new innovative processes. Therefore, since the replacement of this figure is just figurative, its impact on the company's profitability is minimal.

\section{Discussion and Conclusion}

Due to the COVID-19, one of the current main concerns of companies around the world, regardless of their size, is the restoration of company profitability. Considering that corporate health is relevant for different stakeholders, such as investors, managers, policymakers, and industry participants, this is a hot topic. The complexity of the decision situation for companies in financial distress - which includes time pressure and short terms targets leads to an increase in the risk of irrational biases in decision-making as compared to regular business situations. This is the reason why any action on the variables to bring new directors can have relevant consequences on the outcome of the successful turnaround. 
However, by analyzing the existing literature, it is clear that prior empirical research is focused only on few countries (Manzaneque et al., 2016) and, therefore, a structured body of rules regarding this topic is still missing, especially after the COVID-19 (Zattoni \& Pugliese, 2020).

Overall, our results seem to support the theoretical proposition that changes in corporate boards (Lambertides, 2009) likely corresponds to an increase in the company profitability, especially during a turnaround (Elloumi \& Gueyié, 2001; Fernando et al., 2020). Therefore, for restructured company the quality of management or entrepreneurship can serve as a signal about the firm's viability and prospects to a potential capital-provider. In particular, the results of our analysis show that changes in the composition of the board of directors have more influence on the increase of profitability if compared to the renewal of the CEO. This situation seems to be the direct consequence of the peculiar characteristics of the Italian system, where the change of the CEO does not necessarily bring new intellectual capital to the firm, since the CEO is still typically a direct expression of the same shareholder, which caused the crisis for restructured companies.

In conclusion, despite the limitations due to the small size of the sample and its reference to the national context, this study may contribute to previous research in several ways. First, the variables used in the quantitative analysis demonstrates that the renewal of the board of directors affects the probability of increasing the company performance with important and different implications for both healthy and restructured companies. Secondly, our study provides empirical evidence, missing in previous analyses, on the relationship between corporate governance turnover and profitability increase in the Italian context. Finally, the current research takes a step forward compared to the existing literature (Berezinets et al., 2016; Demartini \& Beretta, 2020; Martín-de Castro, Díez-Vial, \& Delgado-Verde, 2019; Santana, Valle, \& Galan., 2017), referring to an unusual concept of corporate crisis for defining the restructured companies. In fact, while the most common definition for empirical studies in literature refers to the access of the firm to a formal procedure, our interpretation is broader and considers the UTP positions, even though they are not involved in a legal state of crisis.

This study could be expanded with constant monitoring of successful remediation cases and furthermore, future research on the topic should better identify other contingencies between the structure of the BoD and the CEO and the causes of profitability increase using more modern approaches, like machine learning techniques.

\section{References}

Abebe, M. A., \& Tangpong, C. (2018). Founder-CEOs and corporate turnaround among declining firms. Corporate Governance: An International Review, 26(1), 45-57. https://doi.org/10.1111/corg. 12216

Adams, R. B., \& Ferreira, D. (2009). Women in the boardroom and their impact on governance and performance. Journal of Financial Economics, 94(2), 291-309. https://doi.org/10.1016/ j.jfineco.2008.10.007

Aghamolla, C., \& Hashimoto, T. (2021). Aggressive Boards and CEO Turnover. Journal of Accounting Research, 59(2), 437-486. https://doi.org/10.1111/1475-679X.12350

Agostini, L., \& Nosella, A. (2017). Enhancing radical innovation performance through intellectual capital components. Journal of Intellectual Capital, 18(4), 789-806. https://doi.org/10.1108/JIC-10-2016-0103

Alipour, M. (2013). An investigation of the association between ownership structure and corporate performance: Empirical evidence from Tehran Stock Exchange (TSE). Management Research Review, 36(11), 1137-1166. https://doi.org/10.1108/MRR-08-2012-0188

Barrick, M., Day, D., Lord, R., \& Alexander, R. (1991). Assessing the utility of executive leadership. The Leadership Quarterly, 2(1), 9-22. https://doi.org/10.1016/1048-9843(91)90004-L

Barker III, V. and Mueller, G. (2002). CEO Characteristics and Firm R\&D Spending. Management Science, 48(6), 782-801.

Ben Barka, H., \& Legendre, F. (2016). Effect of the board of directors and the audit committee on firm performance: a panel data analysis. Journal of Management \& Governance, 21(3), 737-755. https://doi.org/10.1007/s10997-016-9356-2

Bennedsen, M., Pérez-González, F., \& Wolfenzon, D. (2020). Do CEOs Matter? Evidence from Hospitalization Events. The Journal of Finance, 75(4), 1877-1911. https://doi.org/10.1111/jofi.12897

Berezinets, I, Garanina, T., \& Ilina, Y. (2016). Intellectual capital of a board of directors and its elements: introduction to the concepts. Journal of Intellectual Capital, 17(4), 632-653. http://dx.doi.org/10.1108/JIC-01-2016-0003

Brown, M. (1982). Administrative succession and organizational performance: The succession effect. 
Administrative Science Quarterly, 27(1), 1-16

Chen, C. J., Liu, T. C., Chu, M. A., \& Hsiao, Y. C. (2014). Intellectual capital and new product development. Journal of Engineering and Technology Management, 33, 154-173. http://dx.doi.org/10.1016/j.jengtecman.2014.06.003

Contreras, O., Arias, J., \& Maquieira, C. (2021). Risk taking behavior in Chilean listed family firms: a socioemotional wealth approach. International Entrepreneurship and Management Journal, 17(1), 165-184. https://doi.org/10.1007/s11365-019-00628-y

Coughlan, A., \& Schmidt, R. (1985). Executive compensation, management turnover, and firm performance. Journal of Accounting and Economics, 7(1-3), 43-66.

Daily, C. M., \& Dalton, D. R. (1994). Corporate governance and the bankrupt firm: An empirical assessment. Strategic Management Journal, 15(8), 643-654.

Dallocchio, M., Ferri, S., Tron A., \& Vizzaccaro, M., (2020). The use of Z-Score to predict UTP loans. Corporate Ownership and Control, 18(1), 163-178. https://doi.org/10.22495/cocv18i1art13

Dallocchio, M., Lucchin, G., \& Pirrone, C. (2021). Mergers and Acquisitions. Milan: EGEA.

Dalton, D. R., Daily, C. M., Ellstrand, A. E., \& Johnson, J. L. (1998). Meta-analytic reviews of board composition, leadership structure, and financial performance. Strategic Management Journal, 19(3), 269-290. https://doi.org/10.1002/(SICI)1097-0266(199803)19:3<269::AID-SMJ950>3.0.CO;2-K

Deng, S., Intintoli, V., \& Zhang, A. (2019). CEO Turnover, Information Uncertainty, and Debt Contracting. The Quarterly Journal of Finance. https://doi.org/10.1142/S2010139219500010

Demartini, M. C., \& Beretta, V. (2020). Intellectual capital and SMEs' performance: A structured literature review. Journal of Small Business Management, 58(2), 288-332. https://doi.org/10.1080/00472778.2019.1659680

Denis, D. J., \& Denis, D. K. (1995). Performance Changes Following Top Management Dismissals. The Journal of Finance, 50(4), 1029-1057. https://doi.org/10.1111/j.1540-6261.1995.tb04049.x

Dunphy, D., \& Stace D. (1988). Transformational and Coercive Strategies for Planned Organizational Change. Organization Studies, 9(3), 317-334.

Elloumi, F., \& Gueyiè, J. P. (2001). Financial distress and corporate governance: An empirical analysis. Corporate Governance, 1(1), 15-23. https://doi.org/10.1108/14720700110389548

Ernst and Young. (2010). Ambitious, adept and agile: how global entrepreneurs are changing the world - agility and cultural diversity run circles around established firms.

Fernando, J. M. R., Li, L., \& Hou, Y. (2020). Corporate governance and correlation in corporate defaults. Corporate Governance: An International Review, 28(3), 188-206. https://doi.org/10.1111/corg.12306

Finkelstein, S., Hambrick, D., \& Cannella Jr., A. (2009). Strategic leadership: Theory and research on executives, top management teams, and boards, New York, NY: Oxford University Press.

Garzella, S. (2005). Il sistema d'azienda e la valorizzazione delle "potenzialità inespresse”. Una "visione" strategica per il risanamento. Turin: Giappichelli.

Gilson, S. C. (1990). Bankruptcy, boards, banks, and blockholders. Journal of Financial Economics, 27(2), 355-87.

Guest, P. M. (2009). The impact of board size on firm performance: Evidence from the UK. The European Journal of Finance, 15(4), 385-404. https://doi.org/10.1080/13518470802466121

Hilbe, J. (2015). Practical guide to logistic regression, New York, NY: CRC Press.

Hilbe, J. (2009). Logistic regression model, New York, NY: CRC Press.

Hilger, S., Mankel, S., \& Richter, A. (2013). The use and effectiveness of top executive dismissal. The Leadership Quarterly, 24(1), 9-28. https://doi.org/10.1016/j.leaqua.2012.07.001

Jackling, B., \& Johl, S. (2009). Board structure and firm performance: Evidence from India's top companies. Corporate Governance: An International Review, 17(4), 492-509. https://doi.org/10.1111/j.1467-8683.2009.00760.x

Judge, W. Q., \& Zeithaml, C. P. (1992). Institutional and strategic choice perspectives on board involvement in the strategic decision process. Academy of Management Journal, 35(4), 766-94. 
Kanter, R. M., Stein B. A., \& Jick, T. D. (1992). The Challenge of Organisational Change, New York: Free Press.

King, J. E. (2008), Binary Logistic Regression in Best Practices in Quantitative Methods. North Carolina State University: Jason Osborne.

Kowalewski, O., Stetsvuk, I., \& Talavera, O. (2010). Influence of founding-family ownership and managerial regime on firm performance: Evidence from companies on WSE. Family Business Review, 23(1), 45-49. https://doi.org/10.1177/0894486509355803

Lambertides, N. (2009). Sudden CEO vacancy and the long-run economic consequences. Managerial Finance, 35(7), 645-661. https://doi.org/10.1108/03074350910960364

Lappalainen, J., \& Niskanen, M. (2012). Financial performance of SMEs: impact of ownership structure and board composition. Management Research Review, 35(11), 1088-1108. https://doi.org/10.1108/01409171211276954

Lee, J. (2006). Family Firm Performance: Further Evidence. Family Business Review, 19(2), 103-114. https://doi.org/10.1111/j.1741-6248.2006.00060.x

Linck, J. S., Netter, J. M., \& Yang, T. (2008). The determinants of board structure. Journal of financial economics, 87(2), 308-328.

Lohrke, F. T., Bedeian, A. G., \& Palmer, T. B. (2004). The role of top management teams in formulating and implementing turnaround strategies: A review and research agenda. International Journal of Management Reviews, 5/6(2), 63-90. https://doi.org/10.1111/j.1460-8545.2004.00097.x

Malik, M. S., \& Makhdoom, D. D. (2016). Does corporate governance beget firm performance in Fortune Global 500 companies? Corporate Governance The international journal of business in society, 16(4), 747-764. https://doi.org/10.1108/CG-12-2015-0156

Manzaneque, M., Priego, A., \& Merino, E. (2016). Corporate governance effect on financial distress likelihood: Evidence from Spain. Spanish Accounting Review, 19(1), 111-121. https://doi.org/10.1016/j.rcsar.2015.04.001

Martín-de Castro, G., Díez-Vial, I., \& Delgado-Verde, M. (2019). Intellectual capital and the firm: evolution and research trends. Journal of Intellectual Capital, 20(4), 555-580. https://doi.org/10.1108/JIC-12-2018-0221

Mazzotta, R. (2018). The communication of intellectual capital in healthcare organisations: what is disclosed and how? International Journal of Knowledge-Based Development, 9(1), 23-48. https://doi.org/10.1504/IJKBD.2018.090500

Miglani, S. (2014). CEO characteristics and corporate turnaround: evidence from Australia. Corporate Ownership and Control, 11(2), 362-376. https://doi.org/10.22495/cocv11i2c3p5

Miglani, S., Ahmed, K., \& Henry, D. (2020). Corporate governance and turnaround: Evidence from Australia. Australian Journal of Management, 45(4), 1-30. https://doi.org/10.1177/0312896220902225

Minichilli, A., Zattoni, A., \& Zona, F. (2009). Making boards effective: An empirical examination of board task performance. British Journal of Management, 20(1), 55-74. https://doi.org/ 10.1111/j.1467-8551.2008.00591.x

Mishra, R., \& Kapil, S. (2017). Effect of ownership structure and board structure on firm value: Evidence from India. Corporate Governance: The international journal of business in society, 17(4), 700-726. https://doi.org/10.1108/CG-03-2016-0059

O'Kane, C., \& Cunningham, J. (2012). Leadership Changes and Approaches During Company Turnaround. International Studies of Management and Organization, 42(4), 52-85. https://doi.org/10.2753/IMO0020-8825420403

Omondi-Ochieng, P. (2020). Success or failure? Predicting the financial performance of United States national nonprofit sports organisations using binary logistic regressions. Managing Sport and Leisure. https://doi.org/10.1080/23750472.2020.1771196

Paoloni, N., Mattei, G., Dello Strologo, A., \& Celli, M. (2020). The present and future of intellectual capital in the healthcare sector: A systematic literature review. Journal of Intellectual Capital, 21(3), 357-379. https://doi.org/10.1108/JIC-10-2019-0237

Pérez-Calero, L., del Mar Villegas, M., \& Barroso, C. (2016). A framework for board capital. Corporate 
Governance: The international journal of business in society, 16(3), 452-475. https://doi.org/ 10.1108/CG-10-2015-0146

Pitcher, P., Chreim, S., \& Kisfalvi V. (2000). CEO Succession Research: Methodological Bridges Over Troubled $\begin{array}{llll}\text { Waters. Strategic Management } & \text { Journal, 21(6), }\end{array}$ https://doi.org/10.1002/(SICI)1097-0266(200006)21:6<625::AID-SMJ107>3.0.CO;2-A

Pham, H. S. T., \& Nguyen, D. T. (2020). The effects of corporate governance mechanisms on the financial leverage profitability relation. Management Research Review, 43(4), 387-409. https://doi.org/10.1108/MRR-03-2019-0136

Pressman, A. (2007). Kodak's turnaround keeps developing. Business Week, February, 1 https://www.bloomberg.com/news/articles/2007-02-01/kodaks-turnaround-keeps-developingbusinessweekbusiness-news-stock-market-and-financial-advice.

Pukthuanthong, K., Ullah, S., Walker, T. J., \& Zhang, J. (2018). Conflict-induced forced CEO turnover and firm performance. Managerial Finance, 44(9), 1134-1154. https://doi.org/10.1108/MF-06-2017-0227

San Martin-Reyna, J. M., \& Duran-Encalada, J. A. (2012). The relationship among family business, corporate governance and firm performance: Evidence from the Mexican stock Exchange. Journal of Family Business Strategy, 3(2), 106-117. https://doi.org/10.1016/j.jfbs.2012.03.001

Santana, M., Valle, R., \& Galan, J. L. (2017). Turnaround strategies for companies in crisis: Watch out the causes of decline before firing people. BRQ Business Research Quarterly, 20(3), 206-211. https://doi.org/10.1016/j.brq.2017.01.003

Scafarto, V., Ricci, F., Della Corte, G., \& De Luca, P. (2017). Board structure, ownership concentration and corporate performance: Italian evidence. Corporate Ownership \& Control, 15(1-2), 347-359. http://doi.org/10.22495/cocv15i1c2p4

Sudarsanam, S., \& Lai J. (2001). Corporate Financial Distress and Turnaround Strategies: An Empirical Analysis. British Journal of Management, 12(3), 183-199. https://doi.org/10.1111/1467-8551.00193

Susi, V., \& Lukason, O. (2017). Corporate governance and failure risk: evidence from Estonian SME population. Management Research Review, 44(6), 703-720. https://doi.org/10.1108/MRR-03-2018-0105

Terjesen, S., Couto, E. B., \& Francisco, P. M. (2016). Does the presence of independent and female directors impact firm performance? A multi country study of board diversity. Journal of Management \& Governance, 20(3), 447-483. https://doi.org/10.1007/s10997-014-9307-8

Yukl, G. (2008). How Leaders Influence Organizational Effectiveness. The Leadership Quarterly, 19(6), 708-722. http://dx.doi.org/10.1016/j.leaqua.2008.09.008

Zattoni, A., \& Pugliese, A. (2020). Corporate Governance Research in the Wake of a Systemic Crisis: Lessons and Opportunities from the COVID-19 Pandemic. Journal of Management Studies, 58(5), 1405-1410. https://doi.org/10.1111/joms.12693

\section{Notes}

Note 1. Stata is a general-purpose statistical software created by StataCorp. More information can be found on the website https://www.stata.com/

Note 2. ATECO stands for ATtività ECOnomiche and represents the Italian classification of the economic activities.

\section{Copyrights}

Copyright for this article is retained by the author(s), with first publication rights granted to the journal.

This is an open-access article distributed under the terms and conditions of the Creative Commons Attribution license (http://creativecommons.org/licenses/by/4.0/). 